\title{
PHYSICAL CHARACTERISTICS OF CULLED MAGELANG DUCK MEAT AFFECTED BY AGING AND MARINATION IN GINGER EXTRACT
}

\author{
U. Suryanti, V. P. Bintoro, U. Atmomarsono and Y. B. Pramono \\ Faculty of Animal and Agricultural Sciences, Diponegoro University, \\ Tembalang Campus, Semarang 50275 - Indonesia \\ Corresponding E-mail : umisuryanti@gmail.com
}

Received March 04, 2015; Accepted May 15, 2015

\begin{abstract}
ABSTRAK
Penelitian bertujuan untuk memperbaiki karakteristik fisik daging itik afkir dengan marinasi dalam ekstrak jahe dan perlakuan aging. Materi penelitian adalah daging itik afkir dari jenis itik Magelang (umur 2,5 tahun). Ekstrak jahe diperoleh dari hasil ekstraksi dan sentrifugasi rimpang jahe (Zingiber officinale Roscoe) segar. Marinasi daging itik afkir dilakukan dengan perendaman dalam ekstrak jahe pada konsentrasi $0 \%, 5 \%$, dan $10 \%(\mathrm{w} / \mathrm{v})$. Aging dilakukan pada temperatur refrigerasi $\left(10^{\circ} \mathrm{C}\right)$ selama 24, 48, dan 72 jam. Rancangan percobaan adalah rancangan acak lengkap dengan pola faktorial $(3 \times 3)$, dengan 2 faktor utama yaitu konsentrasi ekstrak jahe pada level 0, 5, dan 10\% dan lama aging pada level 24, 48, dan 72 jam, dengan 3 kali ulangan. Terdapat interaksi signifikan antara faktor konsentrasi ekstrak jahe dengan faktor lama aging dalam mempengaruhi kadar air, $\mathrm{pH}$, tekstur (hardness), dan daya ikat air pada daging itik afkir. Karakteristik fisik terbaik daging itik afkir Magelang dihasilkan dari perlakuan marinasi dengan ekstrak jahe konsentrasi 5\% (w/v) dan aging selama 48 jam.
\end{abstract}

Kata kunci : lama simpan, daging itik Magelang afkir, marinasi, karakteristik fisik

\begin{abstract}
The study was aimed to improve the physical characteristics of culled duck meat using marination in ginger extract and aging. The material used were Magelang culled ducks (2.5 years old). Ginger extract was derived from the rhizome of fresh ginger (Zingiber officinale Roscoe). The experimental used was a factorial design ( $3 \times 3)$, with two main factors, namely the concentration of ginger extract and aging time in completely randomized design. Level of ginger extract concentrations were $0,5,10 \%$ and long times of aging were $24,48,72$ hours as combination treatments, and replication for each treatment were 3 times. There was a significant interaction between the factors of aging time with ginger extract concentration in influencing moisture, $\mathrm{pH}$, hardness and the water holding capacity of culled Magelang duck meat. The best treatment to improve the physical characteristics of culled duck meat were marination in 5\% ginger extract and aging for 48 hours.

Keywords : aging, culled Magelang duck meat, marination, physical characteristics
\end{abstract}

\section{INTRODUCTION}

Meat quality associates with technological aspects and sensory characteristics, such as colour, water holding capacity (WHC), cooking looses and texture. Among the sensory characteristics of meat, eating quality, consisting of flavor, tenderness, and juiceness are important characteristics that affect consumer preferences.
Tenderness is the most important character for consumers preferences. Grading of the poultry meat is also based on tenderness, which is related to the age of the poultry. Qualitative changes in muscle tissue during the development of maturity causes the meat from culled duck is less tender than meat from younger duck.

The number of muscle fibers in poultry has not changed but its thickness increases during 
alive. For example, the average diameter of muscle fibers in day-old chicks (DOC), in the age of 8 weeks, and 26 weeks are 8.9 microns, 43 micron, and 48 micron respectively. The increased thickness of the muscle fibers will have an impact on changes in the texture of the meat during the increase of the age. The same condition can occur in ducks, so it is clear that culled duck meat is not tender texture.

The primary structure that affecting meat tenderness is the integrity of myofibrils and the contribution of connective tissue (collagen). Constituent of myofibrilar protein is myosin (35$44 \%$ of the protein of muscle tissue) and actin $(12-15 \%)$. The fat tissue also plays a role in juiceness, tenderness, and flavor of the meat. Juiceness meat associates with the bound water content in the muscle (Iwanowska et al., 2010).

In this study, the physical characteristics of the culled duck meat would be improved by treatment of aging and marination with ginger extract. An aging is often done on cattle carcasses to tenderize meat, but it is rarely performed in poultry. The process of aging is done by conditioning the carcass or meat at low temperatures $\left(4-10^{\circ} \mathrm{C}\right)$, and recommended before deboning. Marinating is a meat treatment using natural ingredients or organic substances called marinade. The purpose of marination are to soften the texture of the meat through proteolysis reaction, to improve flavor, to pressure oxidation of fat, and to inhibits the growth of microorganisms.

One of the herbal plants growing in Indonesia is ginger (Zingiber officinale Roscoe), which are known to have potency as an antioxidant, an antimicrobial and a compound containing proteolytic material. The ginger rhizome also contains zingibain (proteolytic enzyme). The proteolytic activity of zingibain on collagen and actomyosin reportedly able to produce more tenderness meat (Naveena et al., 2004).

The objective of the research was to improve physical characteristics of culled duck meat using marination in ginger (Zingiber officinalle Roscoe) extract and aging.

\section{MATERIALS AND METHODS}

The material used were culled Magelang ducks ( 2.5 years old and no productive anymore). Ginger extract was derived from the rhizome of ginger (Zingiber officinale Roscoe). To obtain ginger extracts, the fresh ginger rhizome (Zingiber officinale Roscoe) were washed, peeled, and sliced. Furthermore, this ginger was blended with cold water $\pm 5^{\circ} \mathrm{C}$ (ginger: distilled water $=2$ : $1 \mathrm{w} / \mathrm{w}$ ) for 2 minutes, then was filtered with filter cloth. The filtrate obtained was centrifuged for 10 min at $3000 \mathrm{rpm}$ at $5^{\circ} \mathrm{C}$. The supernatant was collected and stored as ginger extract (GE). To obtain a ginger extract with a concentration of $5 \%$, 5 grams GE was dissolved in $100 \mathrm{ml}$ of distilled water. Similarly, to obtain a concentration of $10 \%$, as much as 10 grams of GE was dissolved in $100 \mathrm{ml}$ of distilled water.

Marination method was done by soaking the duck meat samples (approximately $100 \mathrm{~g}$ ) in 100 $\mathrm{ml}$ of the ginger extract $(0 \%, 5 \%, 10 \%)$ for 15 minutes and stored (aging) at $5-10^{\circ} \mathrm{C}$ for 24,48 , and 72 hours. Sample preparation in any concentration of GE and time aging were done separately.

The independent treatments were ginger extract concentrations and long times of aging. The dependent variables were the moisture content, protein, fat, $\mathrm{pH}$, water holding capacity (WHC), hardness, protein profile, and organoleptic properties (texture and taste).

The experimental design used was a factorial design (3x3), with two main factors, namely the concentration of ginger extract and aging time in completely randomized design (CRD). The levels of ginger extract concentration were $0,5,10 \%$ and aging time were 24, 48, 72 hours as combination treatments with three replications. Measurement of moisture was done by means of heating method. Measurement of protein content based on the determination of N-total by semimicro Kjeldahl method (Sudarmadji et al., 1984). Measurement of fat content was done by Soxhlet method. Measurement of water holding capacity was done by the method of Hamm (Soeparno, 1992). Testing of texture (hardness) was performed with Lloyd Texture Analyser. Testing of antioxidant activity was done by the method of DPPH radical absorption (Thaipong et al., 2006). Organoleptic test was conducted using Hedonic Scale Scoring Test (Kartika and Hastuti,1988). Analysis of the protein profile of actin, myosin heavy chain (MHC), actomyosin on each sample were performed to determine changes in the structure of duck meat due to the aging process and marination. The method used was sodium dodecyl sulphate-polyacrilamide gel electrophoresis (SDS-PAGE), with reference to 
the procedure of Naveena et al. (2004).

\section{RESULTS AND DISCUSSION}

\section{Moisture}

The interaction between concentration of ginger extract and long time of aging was significantly affected the moisture content of culled duck meat. Marinated treatment with ginger extracts and aging produces culled duck meat with less moisture content than samples without these tratments. Table 1 showed that at the higher concentration of ginger extract and the longer time of aging, the moisture content were lower. The duck meat with concentration of $10 \%$ ginger extract and aging during 72 hours has the lowest moisture content $(73.045 \%)$ and not significantly different from moisture content of duck meat with $5 \%$ ginger extract and aging during 72 hours $(73.226 \%)$.

The ginger extract contained proteolytic enzyme (zingibain) which is able to degrade protein that reduce the function of the protein in water traping in the muscle tissue (Thomson et al., 2006). The water released resulted weep (meat surface becomes wet) and drip (water dripping from meat). With the longer time of aging, the moisture was released more and more, so that the moisture content of the duck meat was lower. Ali et al. (2008) showed that the moisture content of duck meat stored at temperature of $0^{\circ} \mathrm{C}, 10^{\circ} \mathrm{C}$, and $20^{\circ} \mathrm{C}$ were not significantly different. Results of this study showed that moisture of duck meat in ginger extract $0 \%$ and $5 \%$ and aging during 24 hours at $10^{\circ} \mathrm{C}$ were not significantly different $(77.208 \%$ and $76.835 \%)$, but significantly different with the duck meat in $10 \%$ ginger extract
(75.017\%). Similar conditions occurred in the process of aging for 48 hours. It was explained that components in ginger extract affect the moisture decreased of duck meat during storage at low temperatures.

\section{Protein}

The protein levels of culled duck meat ranged from $19.418 \%$ (marination in 5\% ginger extract and aging 48 hours) to $20.380 \%$ (marination in $10 \%$ ginger extract and aging 24 hours). There were no significantly influence of ginger extract and long time of aging on protein levels of duck meat. Table 2 shows the levels of protein of the duck meat with the aging treatment and marination.

Marination and aging process could cause the degradation of proteins which produce peptide or other nitrogen compounds. It caused the nitrogen compounds still measurable even though it was no longer in the form of protein. The used of ginger extract in marination process also plays a role in protein levels of the duck meat. Based on the analysis, protein content in ginger was $12.212 \%$. It was explained that the average protein levels of duck meat with $10 \%$ ginger extract $(20.006 \%)$ was higher than the average protein levels of duck meat with $5 \%$ ginger extract $(19.764 \%)$.

\section{pH-value}

The factors of ginger extract concentration and duration (long time) of aging have a significant effect, and there was interaction between the two factors in influencing the $\mathrm{pH}$ of duck meat. The levels of ginger extract concentration $(0,5,10 \%)$ used in the marination

Table 1. The Moisture Levels of Culled Duck Meat with Aging and Marination in Ginger Extract

\begin{tabular}{|c|c|c|c|}
\hline \multirow{2}{*}{ Aging (hours) } & \multicolumn{3}{|c|}{ Concentrations of Ginger Extract (\%) } \\
\hline & 0 & 5 & 10 \\
\hline & \multicolumn{3}{|c|}{ 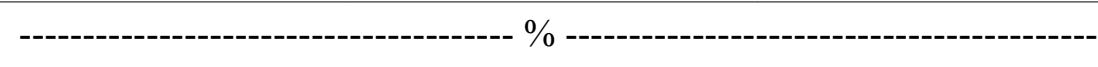 } \\
\hline 24 & $77.208 \pm 0.604^{\text {ap }}$ & $76.835 \pm 0.780^{\text {ap }}$ & $75.017 \pm 0.795^{\mathrm{bp}}$ \\
\hline 48 & $76.313 \pm 0.338^{\mathrm{aq}}$ & $75.484 \pm 0.329^{\mathrm{aq}}$ & $73.724 \pm 0.137^{\mathrm{bq}}$ \\
\hline 72 & $74.204 \pm 0.114^{\mathrm{ar}}$ & $73.226 \pm 0.154^{\mathrm{br}}$ & $73.045 \pm 0.474^{\mathrm{bq}}$ \\
\hline
\end{tabular}

Different superscripts $(a, b, c)$ in the same row and $(\mathrm{p}, \mathrm{q}, \mathrm{r})$ in the same coloumn indicate significantly different $(\mathrm{p}<0.05)$. 
Table 2. Protein levels of Culled Duck Meat with The Aging and Marination in Ginger Extract

\begin{tabular}{|c|c|c|c|}
\hline \multirow{2}{*}{ Aging (hours) } & \multicolumn{3}{|c|}{ Concentration of Ginger Extract (\%) } \\
\hline & 0 & 5 & 10 \\
\hline & \multicolumn{3}{|c|}{ 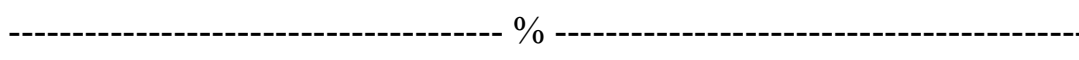 } \\
\hline 24 & $19.785 \pm 2.339$ & $19.995 \pm 1.336$ & $20.380 \pm 1.685$ \\
\hline 48 & $20.129 \pm 2.464$ & $19.418 \pm 0.884$ & $19.659 \pm 1.232$ \\
\hline 72 & $19.859 \pm 1.911$ & $19.879 \pm 0.842$ & $19.979 \pm 1.093$ \\
\hline
\end{tabular}

of culled duck meat at different long times of aging $(24,48$, and 72 hours) resulted different respond on $\mathrm{pH}$ value. The graph in Figure 1 showed that at the longer time of aging, the $\mathrm{pH}$ value of duck meat decreased, and it happened on marination in ginger extract $0 \%, 5 \%$, and $10 \%$. Overall, marination in $10 \%$ ginger extract resulted duck meat with a higher $\mathrm{pH}$ compared to marination in ginger extract $0 \%$ and $5 \%$. The $\mathrm{pH}$ value of duck meat with of ginger extract results marination $0 \%$ and $5 \%$ with the process of aging for 24 hours was not significantly different. Similarly, in the treatment of aging for 48 hours, the $\mathrm{pH}$ of the meat of duck with of ginger extract $0 \%$ and $5 \%$ were not significantly different. It was in accordance with the results of Ali et al. (2008), which showed that the $\mathrm{pH}$ value of duck meat

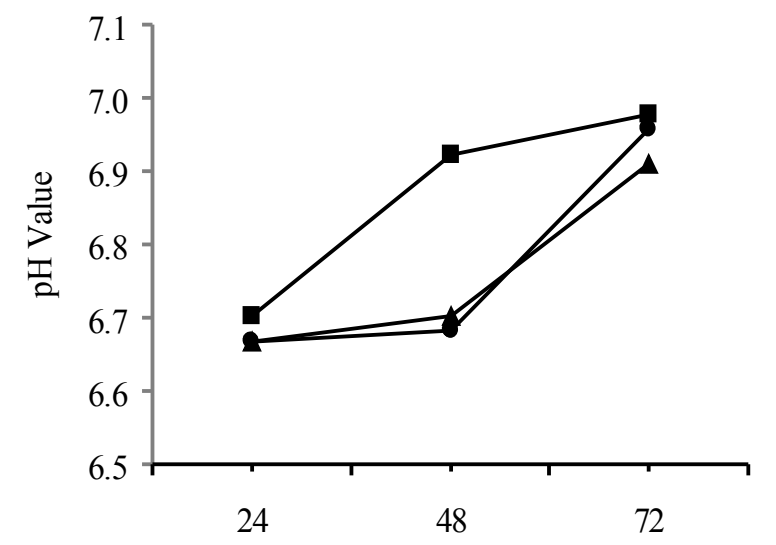

Long Time of Aging (h)

Figure 1. The $\mathrm{pH}$ value of Culled Duck Meat with Aging and Marination in Ginger Extract. The symbols represent marinating in ginger extract $0 \%(\bullet)$, ginger extract $5 \%(\boldsymbol{\Delta})$, and ginger extract $10 \%(\mathbf{m})$. stored at temperatures of $0{ }^{\circ} \mathrm{C}, 10^{\circ} \mathrm{C}$, and $20^{\circ} \mathrm{C}$ was not significantly different after 24 hours.

Ginger extract contains phenol components that tend to be alkaline, so the $\mathrm{pH}$ of duck meat allegedly affected by the $\mathrm{pH}$ of the ginger extract that was used. By the higher concentration of ginger extract, the effect in increasing the $\mathrm{pH}$ of the duck meat was also getting bigger. This was in accordance to previous research by Maiti and Ahlawat (2011), that the treatment with ginger can increase the $\mathrm{pH}$ of the chicken gizzard.

The $\mathrm{pH}$ increasing of the duck meat was also caused by the degradation of proteins including ammonia and resulted trimethylamine compounds. Ginger extract not only contains a proteolytic enzyme (zingibain) that play a role in the breakdown of proteins but also contain phenolic compounds. The higher concentration of the ginger extract and the longer time of the aging treatment produced a higher $\mathrm{pH}$ of duck meat.

\section{Water Holding Capacity (WHC)}

A value of Water Holding Capacity (WHC) of duck meat was influenced by the interaction between factor of ginger extract concentration and factor of aging time. At the longer aging time, water holding capacity of duck meat was getting lower, it happened on marination with ginger extract $0 \%, 5 \%$, and $10 \%$ (Figure 2). This phenomenon expressed that treatments of marination and aging could not affect the declining WHC of the duck meat during storage. The duck meat treated with $10 \%$ ginger extract and aged during 72 hours had the lowest WHC $(13.283 \%)$, and duck meat treated without ginger extract and aged during 24 hour had the highest WHC (36.197\%). Protein in the duck meat contribute to bind the water in the duck meat resulting juiceness in the meat. In the other hand, the proteolytic activity of ginger extract made the 
lower WHC of duck meat due to the role of these proteins decreased, the WHC of duck meat also becomes lower. At high ultimate $\mathrm{pH}$, water holding capacity of the myosin is also high (Dransfield and Sosnicki, 1999). Figure 2 shows the WHC values of the duck meat due to aging and marination treatment in ginger extract.

Some factors that could affect the retention of trapped water is miofibrillar protein, the structure of muscle cells and the amount of extracellular space in the muscle itself (HuffLonergan and Lonergan, 2005). Muscle protein composed by many myofibrils, which ranges from $82-87 \%$. It is estimated that $85 \%$ of the water in the flesh is in the myofibrils. The location of water is affected by changes in volume during phase towards muscle rigidity (rigor). In the phase of rigor occurs cross-bridge between thick and thin filaments (myosin and actin), and reduces the space available for water. During the development of rigidity, the diameter of muscle cells also decreased and the sarcomere shortens, consequently further reducing the space available for water.

\section{Hardness}

Hardness was measured to describe the texture of duck meat affected by aging and marination. High hardness values describe the texture of the meat that was hard (no tenderness). There was a significant interaction between the factor of ginger extract concentration and aging in influencing the hardness of culled duck meat

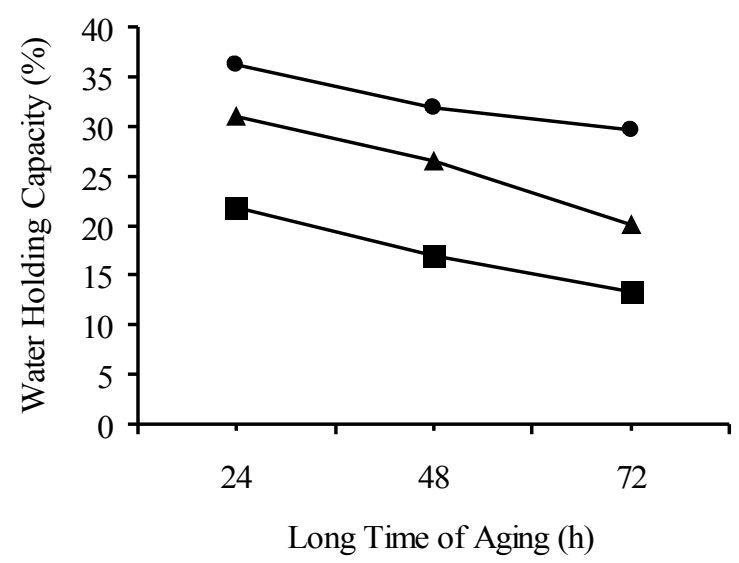

Figure 2. Water Holding Capacity of Duck Meat with Aging and Marination in Ginger Extract. The symbols represent marinating in ginger extract $0 \%(\bullet)$, ginger extract $5 \%(\boldsymbol{\Delta})$, and ginger extract $10 \%($ (匹).
(Table 2). The levels of ginger extract concentration $(0 \%, 5 \%$ and $10 \%)$ on the different long time of aging resulted a different hardness response. Marination with the ginger extract $0 \%$ and $5 \%$ produced the hardness of culled duck meat that decline at the aging 24 hours and 48 hours, and then increased in the aging 72 hours. The rate of these increasing and declining were different. The marination in $10 \%$ ginger extract produced the hardness of culled duck meat that continues to decline during aging 24 hours, 48 hours, and 72 hours. The marination with 5\% ginger extract and aging for 48 hours resulted duck meat with lowest hardness or the most tender. The aging for 48 hours resulted a lower hardness (2531.5 gf) compared to aging for 24 hours (3986.6 gf) and 72 hours (3330.8 gf). Table 2 showed the hardness of duck meat due to aging and marination in ginger extract.

The duck meat changes to become more tender was due to the degradation of myofibril proteins in the tissues. The aging process aims to tenderizing meat at low temperatures, that was 5$10{ }^{\circ} \mathrm{C}$ (the temperature in the refrigerator). At the aging for 24 hours, the degradation process of myofibril protein has not been optimal compared to aging for 48 hours and 72 hours, so as to produce meat with higher hardness. The degradation process of myofibril protein was more optimal in the aging for 48 hours, so there was produce the duck meat with lowest hardness.

Perlo et al. (2006) declared that the aging on chicken carcasses before processing affect the meat tenderness. In the study, the aging was done before the meat was separated from the bone (fillet, deboning), the same as was done in this study. Other researchers suggested that if rigor mortis is not perfect then deboning and freezing resulted the meat becomes hard / rigid, therefore it is recommended to perform aging before deboning (Dawson et al., 1987; Thielke et al., 2005). Alvarado and McKee (2007) stated, that the marination treatment can improve the tenderness of chicken.

The number of muscle fibers associated with changes during growth. Sectional area of muscle fibers in poultry increased with increasing age. Such increase also related with the increase of the amount of fibers that are large, which are usually has a cross-sectional area of three to five times greater than normal, although it can also be produced from some fibers contraction. The ducks that reared extensively have red muscle fibers a lot more and have diameter of red muscle fibers 
Tabel 3. Hardness (gf) of Duck Meat with the Aging Treatment and Marination in Ginger Extract

\begin{tabular}{|c|c|c|c|}
\hline \multirow[t]{2}{*}{ Aging (hours) } & \multicolumn{3}{|c|}{ Concentration of Ginger Extract (\%) } \\
\hline & 0 & 5 & 10 \\
\hline & - & 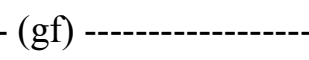 & -------------- \\
\hline 24 & $3590.7 \pm 154.2^{\mathrm{aq}}$ & $3912.2 \pm 412.0^{\mathrm{ap}}$ & $4457.1 \pm 472.7^{\text {ap }}$ \\
\hline 48 & $2443.1 \pm 265.3^{\mathrm{ar}}$ & $1900.1 \pm 432.8^{\mathrm{bq}}$ & $3251.4 \pm 509.0^{\mathrm{aq}}$ \\
\hline 72 & $4740.1 \pm 230.9^{\mathrm{ap}}$ & $2935.2 \pm 264.7^{\mathrm{bpq}}$ & $2317.2 \pm 432.8^{\mathrm{bq}}$ \\
\hline
\end{tabular}

Different superscripts $(a, b, c)$ in the same row and $(p, q, r)$ in the same coloumn indicate significantly different $(\mathrm{P}<0.05)$.

and white muscle smaller than ducks that reared intensively (Dransfield and Sosnicki, 1999).

There are three proteolytic systems in muscle, namely cathepsin, calpain, and the proteasome. In in vivo, the proteasome is responsible on the amount of protein, calpain is responsible on the degradation of the cytoskeleton, whereas lysosomal activity increased after damage (Goldberg et al., 1997). Cathepsin and calpain specifically involved in the process of postmortem proteolysis and weakens the muscle fibers which leads to the tenderness of meat. With the decrease of the proteolytic potency on the growth that faster, the low activity occurs and subsequently the tenderness decreased.

Generally, the tenderness is considered as the most important attribute of meat quality. This is in part due to the quantity or maturity of the connective tissue. Myofibrilar toughness can also be caused by poor handling of carcasses; for example, cooling too quickly which resulted the cold shortening. The development of rigor mortis is caused by the formation of cross-bridges between myosin and actin. Proteolytic enzymes called zingibain can be isolated from the ginger rhizomes. The proteinase in ginger is a thiol proteinase. Proteolytic activity of zingibain on collagen and actomyosin was reported capable of producing meat which more tender (Naveena et al., 2004). The primary structure which affect meat tenderness is the integrity of of myofibrils and the contribution of connective tissue (collagen). Myofibrils consist of myosin (35-44\% of the protein of muscle tissue) and actin (12$15 \%)$. The fat tissue also contributes to juiceness, tenderness, and flavor of the meat. The juiceness related with water holding capacity in the muscle.

The tenderness of culled duck meat was improve during aging, that was physically caused by the fragmentation of myofibrils which involved a proteolytic enzyme. There are two groups of proteolytic enzymes that play a role in the process of softening the meat, that is calcium dependence protease $(\mathrm{CaDP})$ or the other name is calpain ( $\mu$ and m-calpain) and cathepsin group. Both play a role in degrading proteins myofibrils (Przysiezna, 2007).

With a more rapid decrease in $\mathrm{pH}$, myosin be more susceptible to denaturation. Denaturation of myosin which quickly leads to a decrease in water holding capacity, pale, soft, and exudative. In vitro studies showed that the decrease one unit of $\mathrm{pH}$ will increase the rate of denaturation of 12 times (Offer, 1991). Temperature is also a critical factor, with an increase in temperature of $10{ }^{\circ} \mathrm{C}$ denaturation will increase 20 fold. The effects such as PSE (pale, soft, exudative) which harm can be offset by increasing the cooling rate of carcass. Ideally, most of the tenderization of meat tend to be produced at temperatures of around 10 ${ }^{\circ} \mathrm{C}$, at pH 6.2 (Dransfield and Sosnicki , 1999).

The analysis of SDS PAGE was done to identify the protein kind of culled duck meat, and the results are presented in Figure 4. There were actin with molecular weight of 45 kilo dalton $(\mathrm{kDa})$, myosin light chain-2 (MLC-2), myosin light chain-3 (MLC-3), and a polypeptide with a molecular weight less than $14 \mathrm{kDa}$. In the sample of duck meat with $10 \%$ ginger extract, band of actin was thinner than in the duck meat samples without ginger extract and with 5\% ginger extract. While the band of polypeptide (molecular weight of $<14 \mathrm{kDa}$ ) was more clearly seen in samples of duck meat with $10 \%$ ginger extract. Proteolytic activity in ginger extract can caused degradation of actin and myofibril proteins which has a large 


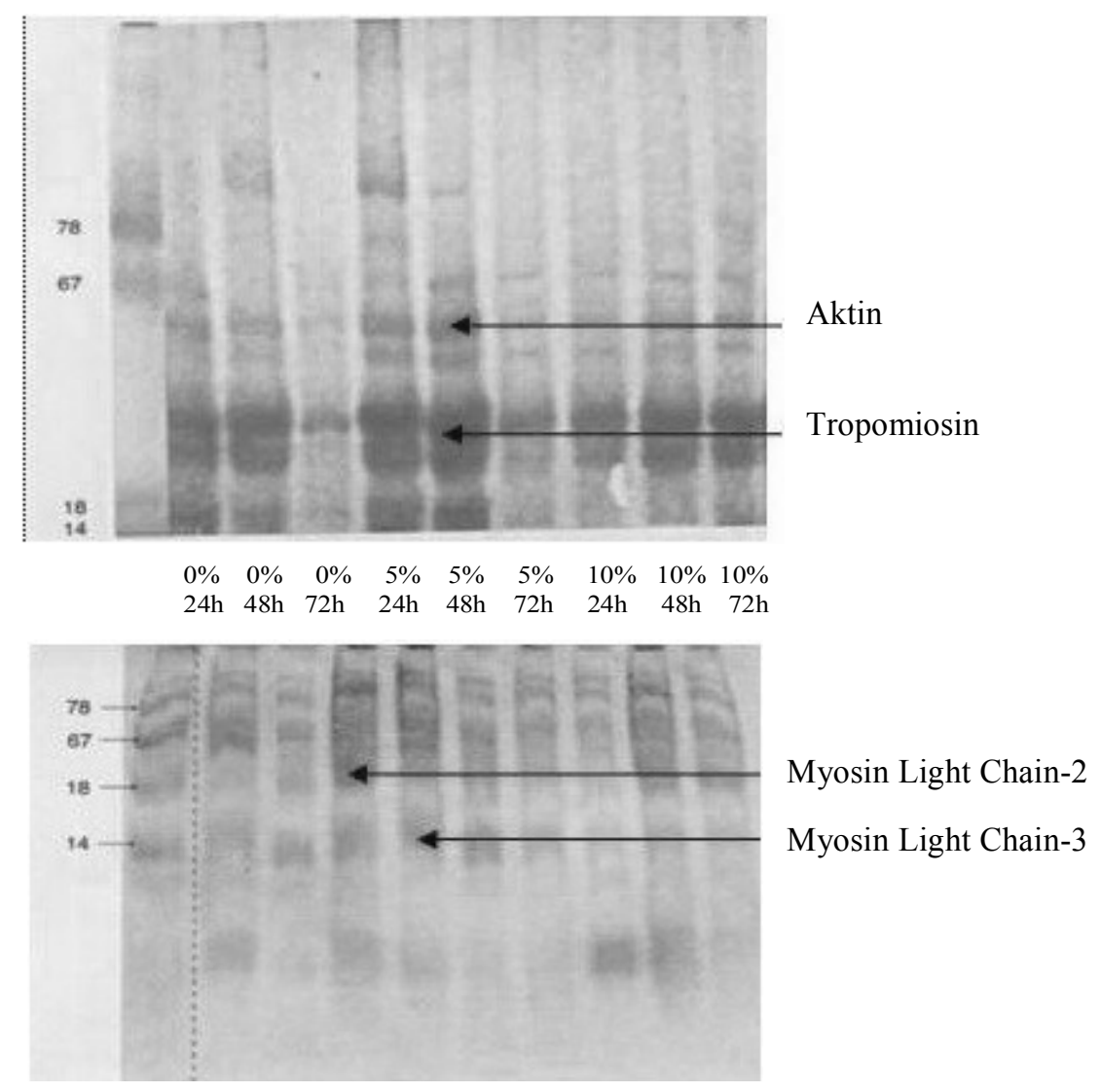

Figure 4. SDS PAGE Analysis Results of Culled Duck Meat by Aging Treatment $(24,48$, and $72 \mathrm{~h})$ and Marination Using Ginger Extract (0, 5, and 10\%)

molecular weight into a polypeptide that has a smaller molecular weight. It was in accordance with the Cha et al. (2002), which researching the changes in myofibrillar proteins and structure of post-mortem mule duck breast as affected by white wine marination.

\section{CONCLUSION}

The physical characteristics of culled duck meat affected by aging and marination treatment in ginger extract. There is an internal proteolytic activity in the culled duck meat during the aging process, which allegedly was the enzyme cathepsin. Zingibain in ginger extracts could increase proteolytic reaction in the culled duck meat, resulting the more simple protein and the peptides with a molecular weight less than 14 $\mathrm{kDa}$. The best treatment to improve the physical characteristics of culled duck meat were marination in 5\% ginger extract and aging for 48 hours.

\section{REFERENCES}

Ali, M.S., H.S. Yang, J.Y. Jeong, S.H. Moon, Y.H. Hwang, G.B. Park, and S.T. Joo. 2008. Effect of chilling temperature of carcass on breast meat quality of duck. Poult. Sci. 87(9):1860-1867.

Alvarado, C. and S. McKee. 2007. Marination to improve functional properties and safety of poultry meat. The Journal of Applied Poultry Research. 16(1):113-120

Cha, S.T., W.T. Chen, and R.G.R. Chou 2002. Changes in myofibrillar proteins and structure of post-mortem mule duck breast as affected by white wine marination. Taiwanese J. Agric. Chem. Food Sci. 40:205-210

Dawson, P., D. Janky, M. Dukes, L. Thompson, and S. Woodward. 1987. Effect of postmortem boning time during simulated commercial processing on the tenderness of broiler breast meat. Poult. Sci. 66:1331-1333 
Dransfield, E. and A.A. Sosnicki. 1999. Relationship between muscle growth and poultry meat quality. Poult. Sci. 78:743-746

Goldberg, A. L., T. N. Akopian, A. F. Kisselev, D. L. Lee, and M. Rohrwild. 1997. New insights into mechanisms and importance of the proteasome in intracellular protein degradation. Biol. Chem. 378:131-140

Huff-Lonergan, E. And. S.M. Lonergan. 2005. Mechanisms of water-holding capasity of meat: The role of postmortem biochemical and structural changes. 2005. 71(1):194204

Iwanowska, A., E. Iwańska, B. Brześ, B. Mikolajczak, E. Pospiech, S. Rosochacki, E. Juszczuk-Kubiak and A. Lyczyński. 2010. Changes in proteins and tenderness of meat from young bulls of four breeds at three ages over 10 days of cold srorage. Anim. Sci. Papers and Reports. 28:13-25.

Kartika, B. and P. Hastuti. 1988. Pedoman Uji Inderawi Bahan Pangan. Pusat Antar Universitas Pangan dan Gizi Universitas Gadjah. Yogyakarta.

Maiti, A. K. and S.S. Ahlawat. 2011. Effect of natural tenderizers on physico-chemical properties of chicken gizzard and goat heart. American J. Food Technol. 6(1):80-86.

Naveena, B.M., S.K. Mendiratta and A.S.R. Anjaneyulu. 2004. Tenderization of buffalo meat using plant proteases from Cucumis trigonus Roxb (Kachri) and Zingiber oficinale Roscoe (ginger rhizome). Meat Sci.
68:363-369.

Offer, G. 1991. Modelling the formation of pale, soft and exudative meats : effects of chilling regime and rate and extent of glycolysis. Meat Sci. 30:157-184

Perlo, F., P. Bonato, G. Teira, R. Fabre and S. Kueider. 2006. Physicochemical and sensory properties of chicken naggets with washed mechanically deboned chicken meat: Research note. Meat Sci. 72:785-788

Przysiezna, E. 2007. Effect of chill storage time on proteolysis and lipid oxidation in vacuum-packed muscles from duck. Polish J. Food Nutr. Sci. 57(4):457-463

Soeparno. 1992. Ilmu dan Teknologi Daging. Gadjah Mada University Press. Yogyakarta.

Sudarmadji, S., B. Haryono, and Suhardi. 1984. Prosedur Analisa Untuk Bahan Makanan dan Pertanian. Liberty. Yogyakarta.

Thaipong, K., U. Boonprakob, K. Crosby, L. Cineros-Zevallos, and D.H. Byrne. 2006. Comparison of ABTS, FRAP and ORAC assays for estimating antioxidant activity from guava fruit extracts. J. Food Comp. Analysis. 19:669-675

Thielke, S., S.K. Lhafi and M. Kuhne. 2005. Effects of aging prior to freezing on poultry meat tenderness. Poult. Sci. 84 (4) : 607-612.

Thompson, E.H., I.D. Wolf, and C.E. Allen. 2006. Ginger rhyzome : a New source of proteolytic enzyme. J. Food Sci. 38(4):652655 